DOI: $10.31866 / 2410-1915.22 .2021 .235919$

UDC 791.228:7.079(477)

\title{
ANIMATION FESTIVAL IN THE MODERN UKRAINIAN CULTURAL SPACE
}

\author{
Kseniia Marakhovska
}

PhD student, ORCID: 0000-0002-7206-9678, marakhovska.kseniia.@gmail.com, International Humanitarian University, 33, Fontanska Doroha St., Odesa, 65000, Ukraine

\section{For citations:}

Marakhovska, K. (2021). Animation Festival in the Modern Ukrainian Cultural Space. Culture and Arts in the Modern World, 22, 233-243. https://doi.org/10.31866/2410-1915.22.2021.235919.

The purpose of the article is to comprehend animation festivals as an important component of the cultural space of modern Ukraine and a decisive factor in the development of the world and domestic animation art. Research methodology. The analytical and synthetic method was used, which made it possible to discover the specifics and directions of development of the large-scale world and domestic animation festivals; owing to the generalisation method, information about animafests was systematised, and their multidimensional abstract review was carried out. The scientific novelty is that the largest world and domestic animation festivals are identified and analysed for the first time, and their specifics are studied. Animation festivals are considered as a kind of indicator of modern culture development. Conclusion. The definition of cultural space as a space of functioning of the animation festival is given, the essential features of the festival as a cultural phenomenon are highlighted. It is ascertained that a festival is a periodic festive event with elements of solemnity and competition, the ultimate goal of which is the demonstration of achievements, creative exchange, professional communication. Festivals differ in direction, themes, programmes. An essential feature of the festival is the presence of a single idea, theme and programme. The information on animation festival activity in Ukraine and the world is generalised and systematised. World and domestic animation festivals are understood from the standpoint of features and directions of their development, new methods and techniques. It is concluded that the demand for animation festivals is increasing every year. Animation festivals have a strong cultural and artistic potential: they showcase new trends and artistic innovations; allow avoiding the isolation of art; allow authors to represent their creations to viewers and experts; provide creative and professional communication. It is noted that animafests are a powerful catalyst for the creative process and contribute to creating the environment for further development and popularisation of animation art.

Keywords: festival; animation; art; culture; animafest; cultural space 


\section{Introduction}

In the cultural space of Modern Ukraine, its various forms and scales, festivals are becoming more widespread. The increase of festival importance creates a need for its scientific research, identification of development tendencies and ascertainment of the impact on the development of animation art in Ukraine and the world. Firstly, the study's complexity is caused by the thematic diversity and number of festivals. Secondly, by the lack of their general documentation, since festivals are not always associated with official structures. Thirdly, animation festivals are a relatively new phenomenon in Ukraine since the period of significant growth in the number of festivals coincides with Ukrainian independence. The relevance of the research is in the understanding that information systematisation about festival activities, identification of the state and directions of development of animation festivals will give grounds to outline the prospects of the festival movement for the development of animation art.

Recent research and publications analysis. M. Bakhtin's works are devoted to the understanding of the festival as a cultural phenomenon. The scientist emphasised the festival dialogicality related to the culture dialogicality, which is "the result of a creative process that is dialogic initially" (Bakhtin, 1975, p. 504). The understanding of the festival activity essence was expanded by studying the play nature of culture by J. Huizinga, who describes the space of human activity as a field of play, which is a way and a universal category of human existence (Huizinga, 1992). K. Zhyhulskyi, Yu. Lotman, A. Barabanov, K. Davydovskyi, M. Lytvynov, S. Liubchenko, R. Nabokov, Yu. Onatskyi, N. Pato, Yu. S. Zuiev, A. Menshykov, P. Nikolaieva, E. Reznikova, O. Yatskov, D. Zubenko, S. Vytkalov and others pay attention to festivals as cultural phenomena in their works. Various aspects of the festival phenomenon are considered in the researches of these and other scientists. Still, a systematic study of the festival movement, including animation film festivals, is not presented.

Therefore, there is a need to carry out a theoretical generalisation of animation festivals, study the features of their functioning in the Ukrainian cultural space, distinguish the largest world and domestic animation art festivals, characterise their specifics and potential for the development of animation art in general.

The scientific novelty of the study is that the most significant world and domestic animation festivals are identified and analysed for the first time, and their specifics are studied. Animation festivals are considered as a kind of indicator of modern culture development. Animation festivals are regarded as a kind of indicator of contemporary culture development.

\section{Purpose of the article}

The purpose of the article is to study animation festivals as an important component of the cultural space of modern Ukraine and a decisive factor in the development of the world and national animation art. 


\section{Main research material}

Today, festivals have become an integral part of our lives and the cultural space. In the context of the problem under consideration, first of all, the term "cultural space" should be clarified. "The words "culture" and "space" are polysemous in themselves, and their combination multiplies polysemy of each other. Culture can be understood in the anthropological sense, as the whole way of life of a particular community, or in the sectoral sense, as a separate sphere of activity" (Hrytsenko, 2019, p. 12). This understanding of cultural space is most acceptable among a large number of definitions. Cultural space is complex, dynamic and multidimensional, the central structural and system forming part of which is human activity on the material, physical and spiritual levels. That's why this is not an abstract category but the living space of human existence, filled, in addition to material achievements, with artefacts of mental nature that cause certain emotional experiences and sensations. Cultural space is just a sketch, a general ground that outlines the contours of human behaviour. Culture organises people lives.

Cultural space is also defined at the legislative level through the prism of activity. The law of Ukraine considers cultural space "as an area in which, according to the legislation, cultural activities are carried out and cultural, information and leisure needs of citizens are met, covering, in particular, radio and television, periodicals and book publishing products, the market of cultural goods, as well as the cultural and artistic environment" (Verkhovna Rada Ukrainy, 2010). This definition gives us grounds to consider animation festivals as a cultural and artistic environment on the one hand and as cultural and artistic activities on the other hand and as an organic component of the cultural space in general.

"Etymologically, the term "festival" comes from the Latin feviae, which means "holidays" "rest days". The French equivalent of the term fete has three meanings: a special day dedicated to the culture of religious ceremonies; public entertainment that is organised on any unusual occasion, such as national holidays, joys of life, happiness, etc." (Shubina, 2006, p. 21, p. 55). The term "festival" comes from the Latin language (lat. festum - holiday, festive banquet) and later it was fixed in old French. Initially, the term referred to a religious holiday, emphasising belonging to it. Only at the end of the 18th century, it occurs as a noun for the first time, but continued, however, to denote a religious celebration (Huizinga, 1992).

The origins of modern festivals can be traced back to the birth of human culture - in ritual and ceremonial actions, festive religious ceremonies, mysteries, carnivals. With the gradual separation of church and secular life, the festivals became closer to their modern understanding.

In "Ancient Greece, the Great Dionysias were the prototype of theatre festivals, and the Great Panathenaia were the origins of festivals of music, variety, dance. The origins of the festival also include the playful nature of the Middle Ages and the Renaissance: carnivals, mummers parade, jugglers' performances, jester parades, competitions of troubadours, minnesingers, histrions, "carnival of masks", "feast of fools", etc." (Men’shikov, 2004, p. 5). 
The first music festivals originated in England in the $18^{\text {th }}$ century and were dedicated to church music. Since then, festivals have been held in many Central European countries, mainly in Germany. They have been particularly widespread since the 40 s of the $20^{\text {th }}$ century. For a long time, festivals existed only as an artistic phenomenon, and their social significance was determined by the significance of this art form respectively. It became possible and necessary to talk about festivals as a social phenomenon only in the $20^{\text {th }}$ century and, most of all, in the age of the information society. Since the second half of the $20^{\text {th }}$ century, mass events have reached a new level. Global changes characterise this period: there is an active reconstruction after military upheavals, the level of technical equipment is increasing rapidly, which contributes to the formation and dynamic development of festivals of this format, which surpass in scale similar actions of the past. "Festivalisation" is becoming a kind of a symbol of socio-cultural changes in the world (Kulichkina \& Mel'nikova, 2015, p. 127).

In the modern sense, a festival is a cultural event of a solemn nature, held in honour of a particular phenomenon, object, person, event or under the auspices of a single idea. Such events usually have a specific theme (one or more). Also, a festival is understood as a demonstration of achievements in the artistic sphere, which can consist of a series of concerts and performances, united by a common name, a single program and held in a particularly solemn atmosphere with a certain frequency (either annually, or every two years, etc.).

The festival is also understood as "a mass celebration that demonstrates achievements in the fields of music, theatre, cinema, variety, etc." (Davydovskyi, 2011). Unlike a mass holiday, the basis of any festival is not a real event but the main idea that determines its specifics, features of organisation, production, directing, and so on. In addition, the festival provides for the presence of participants and spectators, as well as a jury, workshops, the presence of symbols, etc. A festival, unlike a holiday, is characterised by a competitive spirit.

The majority of contemporary art festivals have a competitive basis. The advantage of the festival over the competition is that the priority is not just to become the first but also among equals. That is, the goal is not the victory itself but also the possibility of creative interaction and interpersonal communication. The harmonious combination of the nature of the holiday and the competitive spirit allows a festival to be a universal multifunctional phenomenon that contributes to the development of the creative potential of the individual and society as a whole.

The festival phenomenon is closely connected with socio-cultural processes - it reflects all the diversity and specifics of social relations inherent in modernity. It is about a kind of dialogue, during which a unique cultural unity is created. According to Yu. Moskvichova, there is an active interaction between the artist and the audience during art festivals. "It is the festival that provides an opportunity to unite a large audience in a single space, engage the arts, perceive and appreciate it, and sometimes even take part in the creative process" (Moskvichova, 2014, p. 195). As part of the country's artistic space, Festivals fulfil certain socio-cultural tasks, namely: reproduce art samples, develop tra- 
ditions and spread national cultural heritage in the world, and expand informative and creative connections between festival participants.

In recent years, there have been positive reforms in the field of national culture. There is an active development of festival movements, but there are almost no comprehensive analytical researches. "According to unofficial data, there are more than 1000 festivals related to art and culture in Ukraine" (Dem'ian \& Butsenko, 2018).

Among the variety of festival movements, animation film festivals are a separate direction. The art of animation is complex and multifaceted. It can impress with its unique language and laws. Due to its surreal nature, Animation is able to explore our experience that is elusive to other forms of art and science. "Modern animation is films made by artists in the genre of animation and contains reflections on the problems of the modern person and the challenges of modernity. Animation as a genre has unlimited possibilities. Its only limitation is the screen" (Kyva, 2017). Animation possibilities give grounds to talk about acute socio-political events, diseases, deviations, problems that people prefer not to think about. Owing to formal simplification and associations, it is easier to convey information that is difficult for understanding and evoke empathy.

The animation festival movement has its history and ambassadors. One of the oldest and most significant animation festivals in the world is the Annecy International Animation Film Festival, created in 1956 by Pierre Barbin, a representative of the film distribution management of the Cannes Film Festival, and a group of enthusiastic animators from the largest French amateur film club, Annecy Film Club. In 1960, it was decided to organise a separate independent animation festival based on the unit. In 1985, in parallel with the competition program, the International Animation Film Market (Festival international du film d'animation d'annecy (FIFA) began to work, which gradually became one of the largest and most significant commercial projects in the field of animation. The current program of the Annecy International Animation Film Festival includes about 200 works selected by a jury that receives 2,600 animation films from all over the world annually. The films are divided into several sections: full-length cartoons (starting from 60 minutes), short animated films, television films (TV series, special projects), commissioned films (popular science, advertising, promo), and graduation animated films. It is important for the development of animation art that, in addition to the presentation of films for distribution, representatives of television companies and animation studios can find young talented animators for their staff.

The World Festival of Animated Film in Zagreb - Animafest Zagreb, considered the second oldest animation film festival in Europe is equally famous. Based on the traditions of the Zagreb School of Animated Films, the festival relies on author's films; now, this festival has a reputation as one of the most significant events in the animation environment. The idea of the festival creation arose due to the worldwide recognition of the animated short film, created by the authors from the Zagreb School of Animated Films in the 1950s and 1960s. The festival is recognised by ASIFA (the International Animated Film Association). 
The Ottawa International Animation Festival (OIAF) was founded in 1975 by Canadian animation figures such as Bill Kuhns, Frederik Manter, Prescott J. Wright, Frank Taylor, and Kelly O’Brien. Many Canadian film and media institutions (among them the National Film Board of Canada, Radio Canada, CBC Television, and Cinémathèque québécoise) played a fundamental role in building the festival into its present state. In 1997 the Ottawa International Student Animation Festival (SAFO) was founded and held in alternate years to the larger OIAF. In 2005 the OIAF moved from biennial to annual, and as such, the student categories became part of the main festival.

The Hiroshima International Animation Festival, which is significant in the animation festival movement, was founded by Association International du Film d'Animation or ASIFA as International Animation Festival for the World Peace in 1985 . Today the Festival is considered one of the most respected animated festivals, along with Annecy International Animated Film Festival, Ottawa International Animation Festival and Zagreb World Festival of Animated Films. In 2010, the Festival had nearly 1,937 entries from 57 countries.

A short film, animation and VR festival - Encounters Film Festival - takes place in Great Britain. The festival began in 1995 as Brief Encounters, a oneoff event to mark the centenary of cinema, but it proved so successful that it became an annual attraction. Animated Encounters was set up in 2001 to celebrate and showcase animation. In 2006 the two festivals united as the Encounters Short Film Festival (now known simply as Encounters). In 2010, Encounters became a qualifying festival for the Academy Awards Short Film Category. Then in 2011, Encounters announced a new partnership with the European Film Academy Short Film Initiative, becoming a member of the 15 European festivals that present the nominations for the European Film Academy Short Film Awards.

The Go East Film Festival was founded by Claudia Dillmann, the Director of the German Film Institute - DIF (Deutsches Filminstitut), in 2001. The goEast Festival aims to improve the level of knowledge of the cultural development of Central and Eastern Europe. According to the organisers' opinion, this should help deepen the dialogue between different film schools. Every year, the festival events are widely covered by local media, allowing foreign participants to become recognisable in Wiesbaden and beyond it.

The London International Animation Festival (LIAF) can be proudly called one of the most significant European animation reviews. Founded in 2003, LIAF aims to dispel the popular misconception that animation is just cartoons for kids by screening the broadest possible range of intelligent, entertaining and provocative current films on offer from all around the world as well as retrospectives and specialised sessions from countries and animators who don't usually elicit such attention. The LIAF is even provocative in some ways; the organisers support non-standard and original approaches.

The Anifilm International Festival of Animated Films is important in the world animation festival movement. Anifilm's mission is to present current trends, methods, technologies and animation techniques in its programme. The Festival also supports works in progress and brand new animation projects 
and their authors, producers and distributors. Film professionals worldwide can use Anifilm as a platform for positive confrontation and a meeting place for forging new contacts. Anifilm is aimed at authors and film professionals as well as students, educators, film theorists and all fans of animated production, including children. Anifilm also wants to represent the Czech Republic in an international context on a long-term basis. The Festival is organised by the Citizens' Association for the Support of Animated Film (Občanské sdružení pro podporu animovaného filmu z. s.) / OSPAF. The main aim of the Association is the development and preservation of the cultural heritage of Czech animated film. It wants to popularise animated film in cultural, economic and social spheres.

The International Festival of Animation Arts Multivision, which is held annually in St. Petersburg since 2003, cannot be ignored. Multivision is the first International Animation Festival in Russia aimed at the general public, especially young people and children. The festival is widely known in the international arena, has partnerships with animation festivals and national cinematography councils of leading animation producing countries. The festival program explores the latest developments in animation styles and their influence on other artistic practices. Along with films, the festival presents the full range of contemporary art combined with animation - video art, electronic music, video installations, VJing, multimedia performance. Multivision also produces works of media art, helps young artists in their creative development.

In Ukraine, the KROK and LINOLEUM festivals play a significant role in the development of animation art. The KROK International Animated Films Festival was founded in Kyiv in 1989, and according to international ratings, it was among the top five animation festivals in the world. KROK-2020: Native Harbour received 1,112 submissions for participation from 60 countries. The competition program included almost 100 animated films from 30 countries - works by famous masters and talented debutants. The organisers aim to present the widest variety of styles, techniques, directions of narratives and national cultures at the festival.

LINOLEUM International Contemporary Animation and Media Art Festival is held in Kyiv annually since 2014. It is the biggest showcase of the author's animation in Ukraine. Also, in addition to international and national competitions, the festival consists of a series of workshops and lectures held by the field's best players, experimental animation and video art screenings, thematic non-competitive screenings and program for children. Its main goal is to show that animation is entertainment for children and a form of contemporary art, with the help of which current topics can be raised using new technologies, attracting a large intellectual audience ("Rozpochato pryimannia zaiavok", 2021).

Every year, the festival brings together the most authoritative representatives of the animation industry in the world, promotes cultural exchange, development and popularisation of animation in Ukraine. It is one of the largest world-class animation platforms. Like other world festivals, LINOLEUM promotes the development of the film industry, professional exchange, and the implementation of creative ideas. LINOLEUM is a festival competition that allows 
authors to express themselves, exchange experience, convey an idea, and the audience to communicate with the authors of the films. The festival helps to encourage foreign mentors to help Ukrainian animation projects, get feedback from leading experts. It is very important that the organisers support the integration of the efforts of various educational institutions to improve the level of animation art in Ukraine.

The peculiarity of the national festival is the choice of the annual theme, which is related to the cultural situation of a certain period. For example, Cloud of Dust (2015), Paper Dreams (2016), Heroes and Villains (2017), Fading Borders (2018), Common ground (2019), Becoming Human (2020). This year theme is Presence. Intimacy. Touch. The choice of the topic of 2021 is justified by the situation caused by the global pandemic and quarantine. "Today, physical presence is nearly a rarity. Intimacy is a forbidden entertainment, and touching is a mortal danger. Crisis behaviour became our new standard; the space around us is now holy and untouchable. <...> It turned out that grasping reality is impossible without close contacts, and culture is lifeless if it doesn't resonate with bodies. We suddenly felt our bodies being part of physical cosmology. We discovered that value is determined by comprehensibility, and existence can be fully experienced within arm's and touch reach" ("Rozpochato pryimannia zaiavok", 2021). That's why this topic keeps with the times and relevant.

Since 2020, the LINOLEUM festival has changed the format of its activities slightly. The situation caused by quarantine restrictions has negatively affected the festival activities in general. However, in 2020, the offline festival was organised simultaneously in several cities of our country at open-air venues in compliance with all quarantine standards. The positive aspect is that LINOLEUM established partnerships with online cinemas, where it was possible to watch more than 250 animated films for free, which undoubtedly influenced the audience expansion, the festival business development in particular and the animation art development in general.

In addition to large-scale international animation festivals, there are also regional festival movements in Ukraine. For example, two years in a row, the animafest Zadzerkallia is held in Lutsk, Snail Fest in Berdyansk, etc., which indicate that animation has begun to be perceived as a full-fledged genre of art in our country. Each festival is an integral part of the cultural space of Ukraine, a component of its overall cultural panorama, an exponent of its cultural identity.

\section{Conclusions}

Animation film festivals take a special place in the contemporary cultural space of the world. The study of the most significant animation festivals has shown that the demand for the festival as a cultural product is increasing every year. Animation festivals have a strong cultural and artistic potential. First, animation festivals showcase new trends and artistic innovations. Secondly, they help to avoid the isolation of art, allow authors to represent their creations to viewers and experts, the possibility of creative interaction, interpersonal 
communication, expansion of informative and creative connections between participants, create certain networking during their events so that people who have been in the profession for a long time and novice animators have the opportunity to get acquainted and discuss new projects. Third, every festival is a powerful catalyst for the creative process, which contributes to creating the environment for further development and popularisation of animation art.

Despite the rapid development of the festival movement, animation festivals require the attention of the artistic community, creative initiative and state support, as well as the creation of festival animation distribution in Ukraine, which will support its development and determine the prospects for further research.

\section{References}

Bakhtin, M. M. (1975). Voprosy literatury i estetiki. Issledovaniya raznykh let [Literature and Aesthetics. Research Over the Years]. Khudozhestvennaya literatura [in Russian].

Davydovskyi, K. Yu. (2011). Sotsiokulturni vymiry mizhnarodnoho festyvalnoho rukhu: za rezultatamy IV Mizhnarodnoho muzychnoho festyvaliu "Virtuozy planety" [SocioCultural Dimensions of the International Festival Movement: According to the Results of the IV International Music Festival "Virtuosos of the Planet"]. Topical problems of History, Theory and Practice of Artistic Culture, 26, 257-265 [in Ukrainian].

Dem'ian, V., \& Butsenko, O. (2018). Rol mystetskykh festyvaliv u samorozvytku hromad. Monitorynh praktychnykh pytan [The Role of Art Festivals in Community SelfDevelopment. Monitoring of Practical Issues]. Demokratiia cherez kulturu. https:// demcult.org/rol-misteckikh-festivaliv-u-samoroz/ [in Ukrainian].

Hrytsenko, O. (2019). Kulturnyi prostir i natsionalna kultura: teoretychne osmyslennia ta praktychne formuvannia [Cultural Space and National Culture: Theoretical Understanding and Practical Formation] [Monograph]. Instytut kulturolohii Natsionalnoi akademii mystetstv Ukrainy [in Ukrainian].

Huizinga, J. (1992). Homoludens. V teni zavtrashnego dnya [Homoludens. In the Shadow of Tomorrow] (V. V. Oshis, Trans.). Progress [in Russian].

Kulichkina, G.V., \& Mel'nikova, N. S. (2015). Festival' kak forma mezhkul'turnoi kommunikatsii $\mathrm{v}$ usloviyakh polietnichnogo regiona [Festival as a Form of Intercultural Communication in a Multi-Ethnic Region]. Herald of the Chelyabinsk State Academy of Culture and Arts, 3(43), 127-123 [in Russian].

Kyva, I. (2017, September 25). Festyval LINOLEUM: multyky dlia doroslykh [LINOLEUM Festival: Cartoons for Adults]. Artmisto. http://artmisto.net/2017/09/25/festivallinoleum-multiki-dlya-doroslih/ [in Ukrainian].

Men'shikov, A. M.(2004). Festival'kaksotsiokul'turnyi fenomen sovremennogo teatral'nogo protsessa [Festival as a Socio-Cultural Phenomenon of Modern Theatrical Process] [PhD Dissertation]. GITIS [in Russian].

Moskvichova, Yu. O. (2014). Festyvalno-konkursnyi rukh na Vinnychchyni: dynamika rozvytku [Festival-Competition Movement in Vinnytsia Region: Dynamics of Development]. Culture and Contemporaneity, 1, 192-197 [in Ukrainian].

Rozpochato pryimannia zaiavok u konkursni prohramy LINOLEUM 2021 [Acceptance of Applications for the LINOLEUM 2021 Competition Programs Has Started]. 
(2021, March 6). LINOLEUM. https://inoleumfest.com/uk/news/text/81-call-forentries-2021 [in Ukrainian].

Shubina, I. B. (2006). Dramaturgiya i rezhissura zrelishcha: igra, soprovozhdayushchaya zhizn' [Dramatic Art and Directing a Show: A Game That Accompanies Life]. Feniks [in Russian].

Verkhovna Rada Ukrainy. (2010, December 14). Pro kulturu [On Culture]: Law of Ukraine (№ 2778-VI). https://ips.ligazakon.net/document/TM040628 [in Ukrainian].

\title{
ФЕСТИВАЛЬ АНІМАЩІЇ В СУЧАСНОМУ УКРАЇНСЬКОМУ КУЛЬТУРНОМУ ПРОСТОРІ
}

\author{
Мараховська Ксенія Дмитрівна
}

\author{
Aспірант, \\ ORCID:0000-0002-7206-9678, marakhovska.kseniia@gmail.com, \\ Міжнародний гуманітарний університет, \\ Одеса, Україна
}

Мета статті - осмислення фестивалів анімації як важливого складника культурного простору сучасної України та потужного фактору розвитку світового й вітчизняного анімаційного мистецтва. Методологія дослідження. Використано аналітико-синтетичний метод, що дав змогу з'ясувати специфіку й напрями розвитку наймасштабніших світових та вітчизняних фестивалів анімації; завдяки методу узагальнення систематизовано інформацію щодо аніма-фестивалів та здійснено іхній багатоаспектний реферативний огляд. Наукова новизна полягає в тому, що вперше виділено й проаналізовано наймасштабніші світові та вітчизняні анімаційні фестивалі, висвітлено їхню специфіку. Фестивалі анімації розглядаються як своєрідний індикатор розвитку сучасної культури. Висновки. Подано визначення культурного простору як простору функціонування фестивалю анімації, виділено сутнісні риси фестивалю як культурного феномену. Встановлено, що фестиваль $є$ святковим періодичним заходом, з елементами урочистості та змагальності, кінцевою метою якого є демонстрація здобутків, творчій обмін, професійна комунікація. Фестивалі різняться спрямуванням, тематикою, програмами. Важливою рисою фестивалю є наявність єдиної ідеї, тематики та програми. Узагальнено й систематизовано інформацію щодо анімаційної фестивальної діяльності в Україні і світі. Світові й вітчизняні фестивалі анімації осмислено з позиції особливостей та напрямів іхнього розвитку, нових технік і прийомів. Зроблено висновок, що попит на фестивалі анімації щороку зростає. Фестивалі анімації мають потужний культурний і мистецький потенціал: вони демонструють нові тенденції та мистецькі новації; дозволяють уникнути ізольованості мистецтва; надають авторам змогу виставити свої творіння на огляд глядачів та експертів; забезпечують творчу та професійну комунікацію. Зазначено, що аніма-фестивалі $€$ потужним каталізатором креативного процесу та сприяють створенню середовища для подальшого розвитку й популяризації мистецтва анімації.

Ключові слова: фестиваль; анімація; мистецтво; культура; аніма-фестиваль; культурний простір 


\title{
ФЕСТИВАЛЬ АНИМАЦИИ В СОВРЕМЕННОМ УКРАИНСКОМ КУЛЬТУРНОМ ПРОСТРАНСТВЕ
}

\author{
Мараховская Ксения Дмитриевна
}

Аспирант, ORCID: 0000-0002-7206-9678,marakhovska.kseniia.@gmail.com, Международный гуманитарный университет, Одесса, Украина

Цель статьи - осмысление фестивалей анимации как важной составляющей культурного пространства современной Украины и мощного фактора развития мирового и отечественного анимационного искусства. Методология исследования. Использован аналитико-синтетический метод, который позволил выяснить специфику и направления развития самых масштабных мировых и отечественных фестивалей анимации; благодаря методу обобщения систематизирована информация о фестивалях анимации и предоставлен их многоаспектный реферативный обзор. Научная новизна заключается в том, что впервые выделены и проанализированы самые масштабные мировые и отечественные анимационные фестивали, освещена их специфика. Фестивали анимации рассматриваются как своеобразный индикатор развития современной культуры. Выводы. Дано определение культурному пространству как пространству функционирования фестиваля анимации, выделены сущностные черты фестиваля как культурного феномена. Установлено, что фестиваль является праздничным периодическим мероприятием, с элементами торжества и состязательности, конечной целью которого является демонстрация достижений, творческий обмен, профессиональная коммуникация. Фестивали различаются направлениями, тематикой, программами. Важной чертой фестиваля является наличие единой идеи, темы и программы. Обобщена и систематизирована информация об анимационной фестивальной деятельности в Украине и в мире. Мировые и отечественные фестивали анимации осмыслены с позиции особенностей их развития, новых техник и приёмов. Сделан вывод, что спрос на фестивали анимации ежегодно растет. Фестивали анимации имеют мощный культурный и художественный потенциал: они демонстрируют новые тенденции и художественные новации; позволяют избежать изолированности искусства; дают авторам возможность выставить свои творения на суд зрителей и экспертов; дают возможность для творческой и профессиональной коммуникации. Отмечено, что анима-фестивали становятся мощным катализатором креативного процесса и способствуют созданию среды для дальнейшего развития и популяризации искусства анимации.

Ключевые слова: фестиваль; анимация; искусство; культура; анима-фестиваль; культурное пространство 